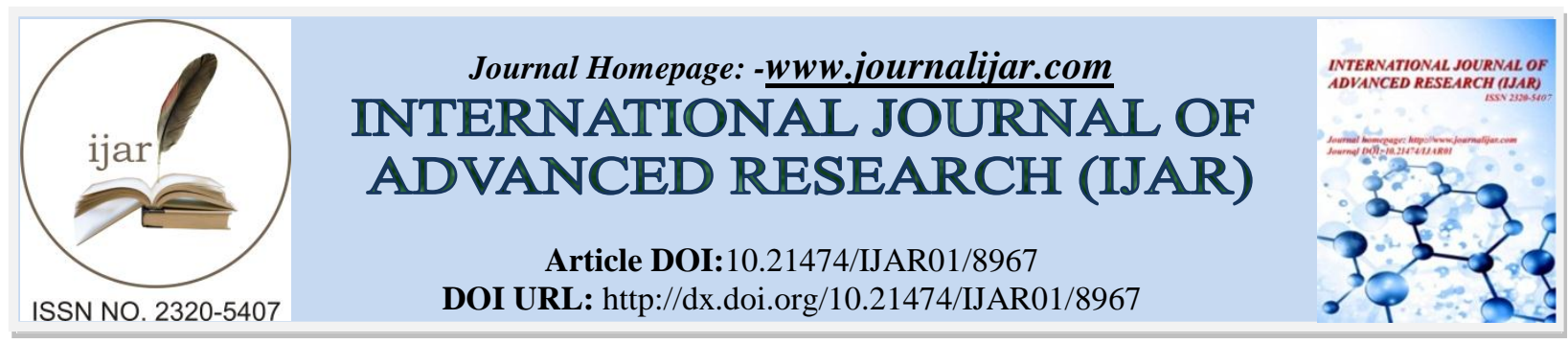

RESEARCH ARTICLE

\title{
MECHANICAL PROPERTIES OF MINERAL STONE WOOL FIBERS BASED ON MIXTURE OF BLAST FURNACE SLAG AND DIABASE.
}

\author{
Aida Imamović ${ }^{1}$, Benjamin Bizjan ${ }^{2}$, Raif Seferović ${ }^{3}$, Primož Mrvar ${ }^{4}$ and David Bombač ${ }^{4}$ \\ 1. University of Zenica, Faculty of Metallurgy and Technology, Zenica, BiH. \\ 2. University of Ljubljana, Faculty of Mechanical Engineering, Ljubljana,SLO. \\ 3. University of Zenica, Institute "Kemal Kapetanovic", Zenica, BiH. \\ 4. University of Ljubljana, Faculty of natural sciences, Ljubljana, SLO.
}

\section{Manuscript Info}

..........................

Manuscript History

Received: 22 February 2019

Final Accepted: 24 March 2019

Published: April 2019

Key words:-

mineral wool, fibers, blast furnace slag, spinning machine.

\begin{abstract}
Metallurgical slag is a valuable, but insufficiently used by-product especially from the production of iron and steel.This paper investigates the potential of employing the mixtures of blast furnace slag and naturally occurring minerals in production of mineral wool. Fibers were produced from molten batches of slag-diabase mixtures, and then tested for mechanical properties. Young's modulus and surface hardness of individual fibers were determined by the nanoindentation procedure. Based on experimental results, it can be concluded that mechanical properties of produced fibers are comparable to the properties of nonslag stone wool fibers. This leads to a conclusion that blast furnace slag can be used as the main component in production of mineral wool, largely replacing the natural minerals.
\end{abstract}

Copy Right, IJAR, 2019,. All rights reserved.

\section{Introduction:-}

Mineral wool is a general name for a non-metallic inorganic fibres, which has found wide application in all sectors of industry, transport and construction due to its combined advantages of excellent thermal insulation ability, antisound insulation and fire resistance properties. The two best known types of mineral wool are stone wool and glass wool. Mineral wool production (consider scheme presented in Figure 1) is a highly complex process consisting of several different production phases. The phases which most significantly affect the mineral wool quality are the melt fiberization on the spinning machine (spinner) and primary layer formation in the collecting chamber [1]. The fiberization process is carried out by spinning of melt spinning on the surface of rotating wheels [2] or by extrusion of melt through the wall of a perforated rotor [3], with the use of the latter device limited to production of glass wool, while the former device can be used for any kind of melt and is typically employed in stone wool production. Fibers formed on the spinner are then transported to the collection chamber by means of coaxial air flow, forming a primary layer of mineral wool that then undergoes further production phases.

Corresponding Author:-Aida Imamović.

Address:-University of Zenica, Faculty of Metallurgy and Technology, Zenica, BiH. 


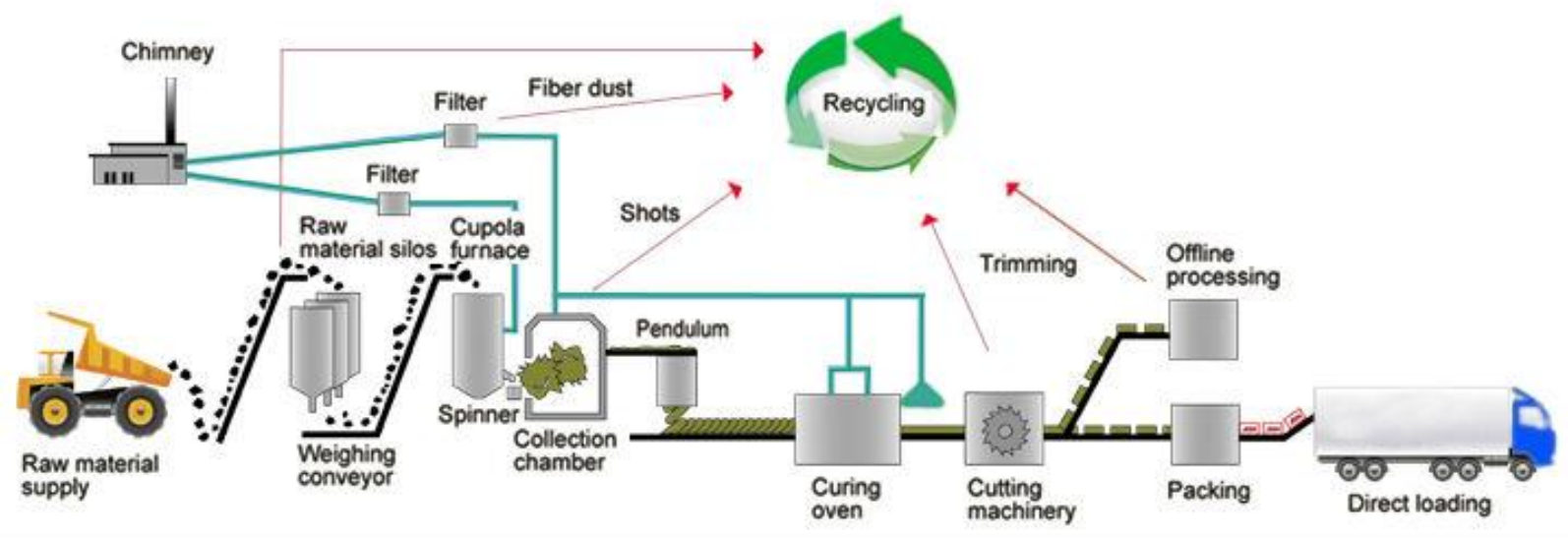

Figure 1:-Manufacturing process of mineral wool

The stone wool fibers are produced at high temperatures, incorporating various raw materials, which combine to impart superior tensile strength and other mechanical properties. Most commonly, natural raw materials such as basalt, diabase, limestone and dolomite are mixed in a batch and fed into a furnace where melt is prepared. Due to increasing environmental standards and awareness, there is a growing interest in replacement of the natural raw materials with industrial waste materials such as blast furnace slag that remain largely unused after deposition to landfills.

Blast furnace slag exhibits a chemical composition similar to natural aluminosilicate minerals [4], and can therefore partially or completely replace the natural raw materials while still producing melt with favorable fiberization properties [5]. Mineral wool produced mostly from slag is known as slag wool and is characterized by properties similar to stone wool [1]. With that said, there are many different kinds of slags depending on the metal smelted (e.g. blast furnace slags, metallic slags), and a good knowledge of slag and aluminosilicate melt properties is important to produce high quality mineral wool. The most important melt properties to be controlled during the fiberization process are density [4], surface tension [4], viscosity [6] and liquidus temperature [7, 8]. Once fibers are produced, their quality is decided by their geometric features (distribution of diameter and length), as well as mechanical properties such as Young's modulus [9, 10] and surface hardness [10] of fibers.

The present paper investigates the possibility to produce mineral wool by using blast furnace slag mixed with natural raw materials such as diabase. Blast furace slag is an abundant and inexpensive raw material readily available from iron and steel plants. The case study is based on evaluation of the potential for the use of blast furnace slag from ArcelorMittal steel factory in Zenica, Bosnia and Herzegovina, mixed with locally available mineral raw materials to prepare and fiberize the melt [11].

\section{Experimental Part}

The blast furnace slag used in this experiment was collected from ArcelorMittal Zenica. The main component of blast furnace was $\mathrm{CaO}$ and $\mathrm{SiO}_{2}$, table 1 [11]. Diabase as an additive was added to modify the blast furnace slag. Mineral fiber sample was produced on the basis of $50 \%$ of a blast furnace slag and $50 \%$ of diabase, which was used in the study.

Table 1:-Chemical composition of blast furnace slag [11]

\begin{tabular}{|l|l|}
\hline Oxide & Mass percent, $\%$ \\
\hline $\mathrm{SiO}_{2}$ & 38.12 \\
\hline $\mathrm{CaO}$ & 42.3 \\
\hline $\mathrm{MgO}$ & 5.48 \\
\hline $\mathrm{Al}_{2} \mathrm{O}_{3}$ & 8.88 \\
\hline $\mathrm{MnO}$ & 3.10 \\
\hline $\mathrm{Fe}_{2} \mathrm{O}_{3}$ & 0.29 \\
\hline
\end{tabular}


The primary layer formation process is an important part of the mineral wool production line.In order to simulate a primary layer formation and one part of slag wool production process a laboratory experiment was performed on a model spinning machine [3].

The mixtures of blast furnace slag and diabase (BFSD sample) was melted in an induction furnace and homogenized at a temperature of $1450^{\circ} \mathrm{C}$. Mineral melt first enters the melt reservoir and is then supplied to the spinning machine with a hollow perforated rotor and a vertical collecting chamber, figure 2 .

The free-falling stream of melt was then fiberized on a laboratory spinning machine. To attain fiberization, melt was poured from the crucible onto an adjustable position melt channel, from where it flowed onto the preheated wheel surface. Upon contact with the wheel surface, melt forms a thin radial film along the wheel perimeter. Under the action of inertial and capillary forces, fiberization process occurred and resulting fibers were contained on the inner perforated wall of the spinning machine casing [11].

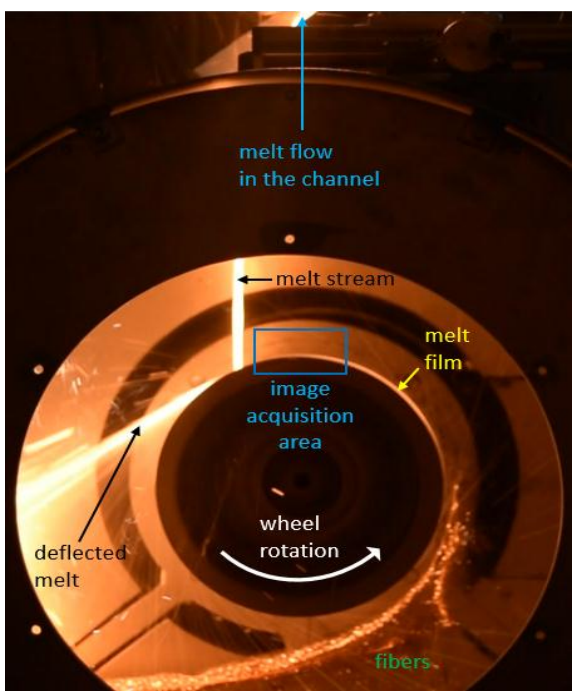

Figure 2:-Laboratory spinning machine used for fiberization (adapted from [12])

A quality primary layer is defined by a low degree of spatial fluctuations in thickness and density of the fiber deposit, and is very important for achieving optimal insulation and mechanical properties of the end products [13]. A good quality primary layer is characterized by a homogeneous structure of the fiber deposit.

The most commonly used measurement method is the camera visualization of the mineral wool primary layer. Examples of fiber formation (primary layers) are shown in figure 3 from high-speed images of the formation process (acquisition window shown in figure 2). Initial disturbances seen as bulges on the melt film are gradually extended into liquid ligaments, which then detach from the film and solidify to fibers. Ligament ends retain the initial bulbous shape and may be detached from the ligament body to solidify to shots or "pearls", or solidify on the fiber.

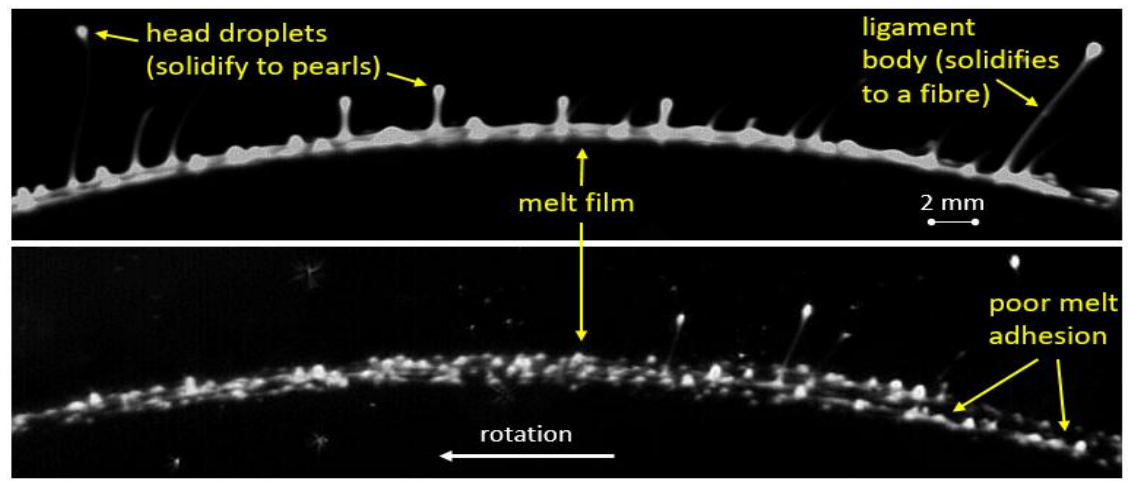

Figure 3:-Examples of silicate melt film on the spinning wheel in the fiberization process 
This phenomenon of relatively poor fiber formation is due to weak adhesion forces, which are primarily related to the properties of melt material and presence of a low temperature surface of the centrifuge wheel. The above does not affect the quality of the fibers produced on the surface of the rotating wheel, but rather on the proportion of the non-fiberizing material. The reason for this is a significance of presence of non - fiberizing material in the samples.

\section{Results And Discussion:-}

\section{modules and chemical analysis of primary fiber layer}

Chemical composition of mixture significantly affects the temperature region of melting, acidity and the melt viscosity at a given temperature and measured mechanical properties depend on fiber diameter and substrate [14].

Acidity module, viscosity and anion structure coefficient were calculated for the BFSD mineral mixture of equal parts of the blast furnace slag and diabase, table 2, [15]. These values are within the prescribed limits for obtaining potentially good mineral wool properties.

Table 2:-Values of calculated modules [15].

\begin{tabular}{|l|l|}
\hline Module & Value \\
\hline Acidity module & 1.22 \\
\hline Viscosity module & 0.995 \\
\hline Anion structure coefficient & 3.15 \\
\hline
\end{tabular}

After melting the BFSD mineral mixture, its chemical composition was determined. Chemical composition of BFSD sample was determined by the XRF method on a powdered sample, table 3.

Table 3:-Chemical composition of molten BFSD sample

\begin{tabular}{|l|l|l|l|l|l|l|l|l|l|}
\hline Oxide & $\mathrm{SiO}_{2}$ & $\mathrm{Al}_{2} \mathrm{O}_{3}$ & $\mathrm{Fe}_{2} \mathrm{O}_{3}$ & $\mathrm{MgO}$ & $\mathrm{CaO}$ & $\mathrm{K}_{2} \mathrm{O}$ & $\mathrm{TiO}_{2}$ & $\mathrm{MnO}$ & $\mathrm{Cr}_{2} \mathrm{O}_{3}$ \\
\hline Mass \% & 46.01 & 11.59 & 3.86 & 9.93 & 22.70 & 0.64 & 0.66 & 1.72 & 0.03 \\
\hline
\end{tabular}

Solid fibers trapped inside the spinner casing were collected for analysis along with rocks into which excess melt solidified on the bottom of the casing. The cross-sectional diameter of the fiber is about 11 microns. Figure 4 shows macro images of fibers produced from BFSD mixture combined with microscope images of fibers inserted in metallographic samples.

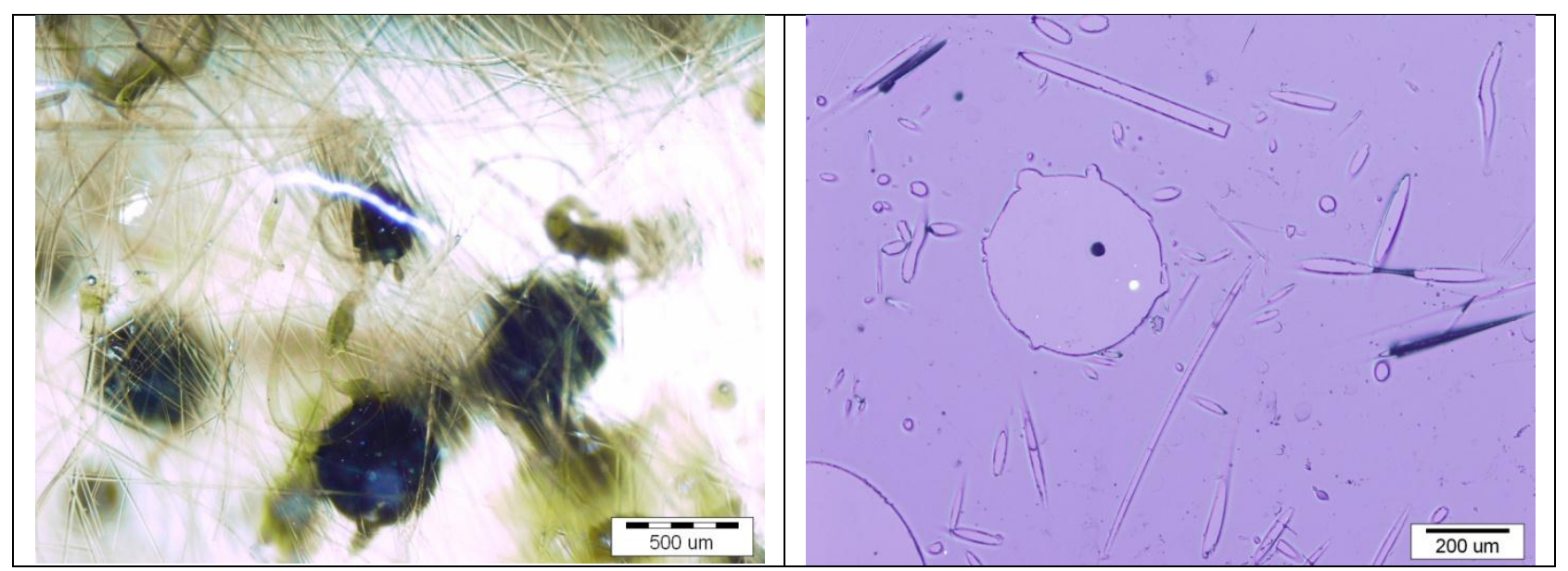

Figure 4:-Macro in micro image of produced fibers based on BFSD mixture [11].

From the presented images on the micro and macro level of BFSD fibers on figure 4.and the corresponding analysis of the average diameter of the fibers in the samples, the conclusion is that the fibers' structure is comparable with the sample structures as obtained on previous analysis cases with other materials from the area of stone wool production processes [11]. 


\section{Nanoindentation Results Of Primary Fiber Layer}

Samples of BFSD primary layer were inserted into epoxy resin and prepared by a standard metallographic method with grinding and polishing, for the purpose of optical microscopy and mechanical nanoindentation tests [16, 17]. Mechanical tests were performed on a Nanoindenter AG 200 using DCMII measuring head which allowed greater sensitivity under small loads. The method used for tests was continuous sample stiffness measurement, where the tip slightly oscillates as the load and consequently imprint depth are increased. The measurement result was Young's modulus and sample hardness as a function of imprint depth. Imprints on fibers based on BFSD mixture (100x magnification) shows figure 5 .

Considering the fact that hardness and Young's modulus values decrease with imprint depth, reference values were averages between the depth of $100 \mathrm{~nm}$ and $200 \mathrm{~nm}$.
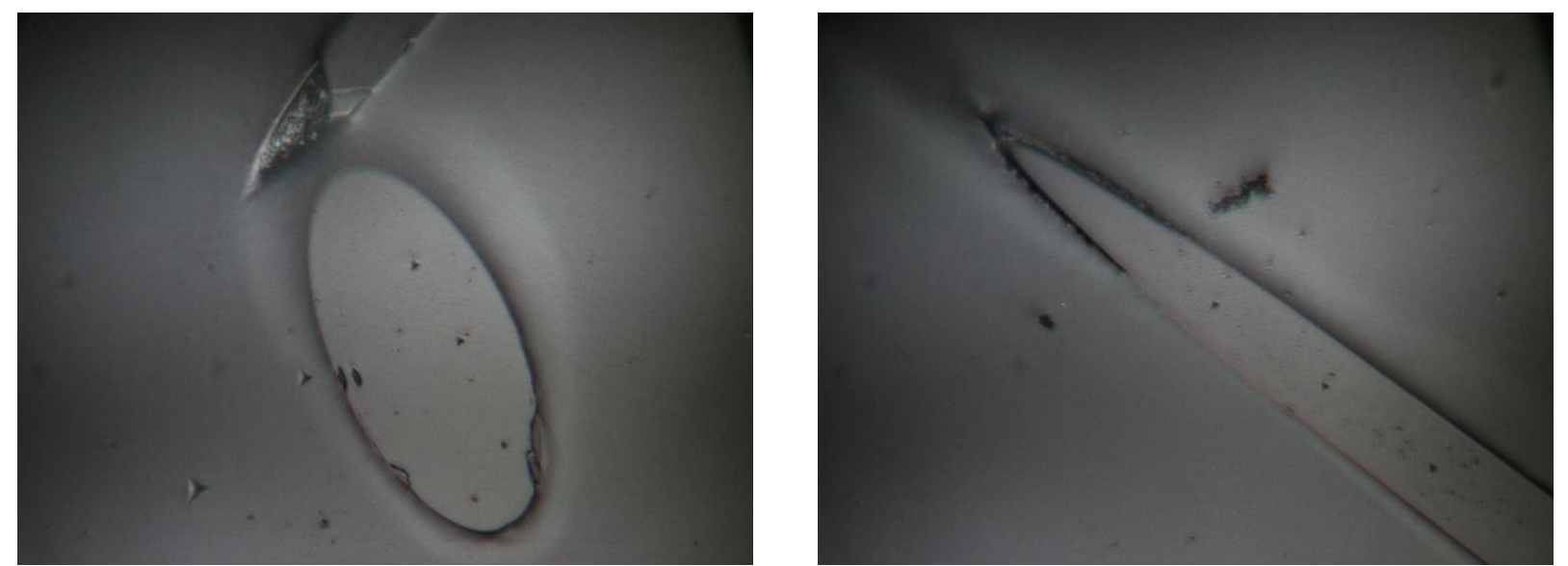

Figure 5:-Imprints on fibers based on BFSD mixture (100x magnification), [11].

Average measurements of Young's modulus and hardness on sample based on BFSD mixture between the depth of $100 \mathrm{~nm}$ and $200 \mathrm{~nm}$, related to imprints presented in figure 4, are given in table 5 .

Table 5:-Mean modulus and hardness of BFSD mixture [11]

\begin{tabular}{|c|c|c|}
\hline Sample & Young's module, GPa & Hardness, GPa \\
\hline BFSD fiber & 70.6 & 7.8 \\
\hline
\end{tabular}

The obtained mechanical properties of BFSD sample are comparable with the mechanical properties of other producers in the field of mineral wool [11].

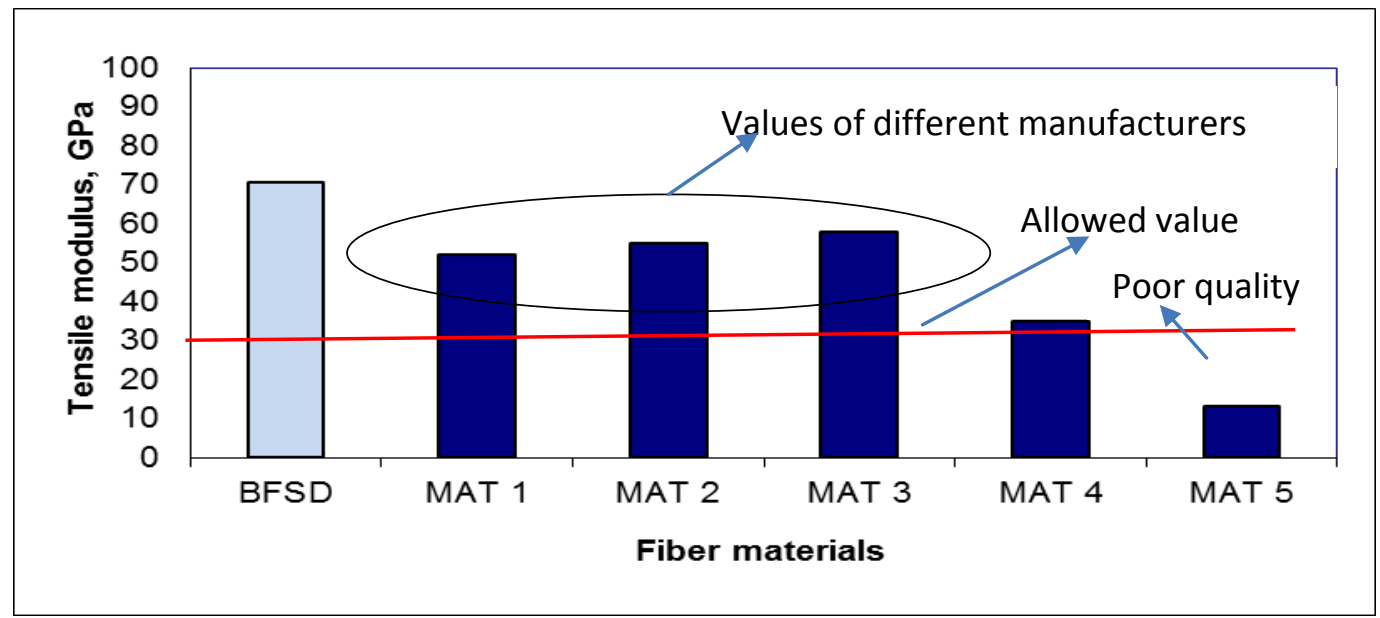

Figure 5:-Comparison of mechanical properties of fiber materials of different manufacturers 
Following the results of a study carried out on the formation of mineral wool fibers based on mixture of blast furnace slag, it can be concluded that the BFSD prepared mixtures can be used for production of the mineral fibers.

The use of blast furnace slag as the dominant component in the production of stone wool requires a comprehensive analysis from the aspect of quality and it has to be environmentally and economically justified.

\section{Conclusions:-}

1. Mineral wool is one of the most commonly used insulation materials.

2. Using blast furnace slag in stone wool production reduces the consumption of natural minerals.

3. The process of the mineral wool primary layer formation was studied experimentally on a model spinning machine with mineral mixture based on blast furnace slag.

4. Chemical composition of mixture significantly affects the melt viscosity and mechanical properties of primary fiber layer.

5. Research of the primary layer mechanical properties based on mixture of blast furnace slag and diabase shows that the blast furnace slag can be used for production of mineral wool.

6. The use of blast furnace slag as the dominant component in the production of stone wool requires a comprehensive analysis from the aspect of mineral wool quality.

\section{Acknowledgements:-}

The authors gratefully acknowledge the financial support by the Federation BiH Ministry of Science and Education.

\section{Literature:-}

1. Širok B, Blagojević B, Bullen PR: Mineral wool: production and properties. Cambridge: Woodhead Publishing Limited, 2008.

2. Širok B, Bizjan B, Orbanić A, Bajcar T: Mineral wool melt fiberization on a spinner wheel. Transactions of the Institution of Chemical Engineers. Part A, Chemical engineering research and design, 2014; 92(1): 80-90.

3. Kraševec B, Bizjan B, Širok B, Glass wool layer formation in the collecting, Glass Technol., Eur. J. Glass Sci. Technol. A, 2017; 58 (1): 1-7.

4. Allibert M, Gaye H. et al.: Slag Atlas. Düsseldorf: Verlag Stahleisen GmbH, 1995, p.616.

5. Zhao D, Zhang Z, Liu L, Wang X: A Novel kinematic model for molten slag fiberization. Cermaics International, 2015 ; 41, 5677-5687.

6. Gan L, Xin J, Zhou Y: Accurate viscosity calculation for melts in $\mathrm{SiO}_{2}-\mathrm{Al}_{2} \mathrm{O}_{3}-\mathrm{CaO}-\mathrm{MgO}$ systems. ISIJ International, 2017; 57(8), 1303-1312.

7. Dong J, Zhang D, Gan L: An empirical formula for accurate calculation of liquidus temperature of blast furnace slags in $\mathrm{SiO}_{2}-\mathrm{Al}_{2} \mathrm{O}_{3}-\mathrm{CaO}-\mathrm{MgO}$ system. Ironmaking \& Steelmaking; 2017: DOI: 10.1080/03019233.2017.1340545

8. Jang $\mathrm{K}$, Ma X, Zhu J, Xu H, Wang G, Zhao B: Phase equilibria in the system " $\mathrm{FeO}$ " $-\mathrm{CaO}-\mathrm{SiO}_{2}-\mathrm{Al}_{2} \mathrm{O}_{3}-\mathrm{MgO}$ with $\mathrm{CaO} / \mathrm{SiO}_{2}$ 1.3. ISIJ International; 2017, 48(3), 1547-1560.

9. El-Moneim AA, Youssog IM, Shoaib MM: Elastic moduli prediction and correlation in $\mathrm{SiO}_{2}$-based glasses. Materials Chemistry and Physics. 1998; 52, 258-262.

10. Tiegel M, Hosseinabadi R, Kuhn S, Herrmann A, Rüssel C: Young's modulus, Vickers hardness and indentation fracture toughness of alumino silicate glasses: 2015.

11. Projekat: Osvajanje proizvodnje i karakterizacija kamene vune na bazi supstitucije prirodnih sirovina", Federalno ministarstvo obrazovanja i nauke, Univezitet Zenica, Zenica, BiH Projekat FMON 2017.

12. Chen J, Mrvar P, Širok B, Bizjan B: Melt film adhesion dynamics on spinning wheels. Glass Technology; 2018.

13. Bizjan B, Peternelj M, Šrok B: Mineral wool primary layer formation in collecting chamber. Journal of Mechanical Engineering 62, 2016; 3: 181-188.DOI:10.5545/sv-jme.2015.2995

14. Du PP, Lang Y, Li ZH, Zhang YZ, Effect of acidity coefficient of molten slag on properties of slag. Guocheng Gongcheng Xuebao/The Chinese Journal of Process Engineering, 2015; 15/3:518-523.

15. Imamović A, Jovanović M, Hadžalić M, Oruč M: Perspektiva upotrebe visokopećne troske kao zamjena prirodnim mineralnim agregatima u tehnologiji proizvodnji kamene vune. 4. Međunarodna naučna konferencija, COMETa 2018, Jahorina 27-20.novembar 2018.

16. Berkovich E: Three-faceted diamond pyramid for studying microhardness by indentation. Zavodskaya Laboratoria. $1950 ; 13,345-352$.

17. Ban H, Karki P, Kim YR: Nanoindentation test integrated with numerical simulation to characterize mechanical properties of rock materials. Journal of Testing and Evaluation, 2014; 42, 3: 1-10. 